Synthesis of Natural

\title{
Synthesis of Amphidinolide P
}<smiles>CCC(=O)OCC1CO1</smiles>

A<smiles>CC(=O)C(C)CO</smiles>

B<smiles>C=C(/C=C/[C@H](O)C(C)C(=C)C)CC1OC1[C@@H]1CC(=C)C(C)C(=O)CC(=O)O1</smiles>

H

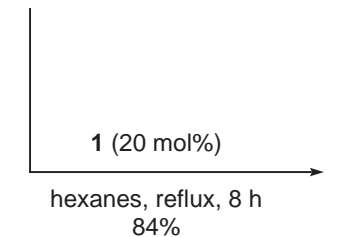
macrolactonization/hemiacetal formation

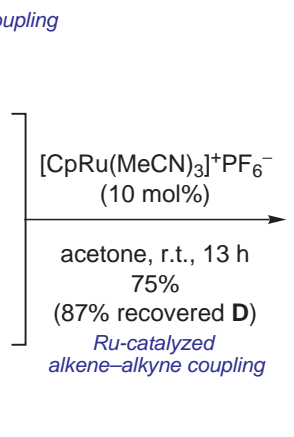

D<smiles>C=CCC(O)CC(=C)C(C)C1=CC(=O)O1</smiles>

(3.5 equiv)<smiles>C=C(/C=C/[C@H](O[SnH3])C(C)C(=C)C)C/C=C/[C@H](O)CC(=C)C(C)[C@H]1CC(=O)O1</smiles>

$\mathrm{Ti}(i-\mathrm{PrO})_{4},(-)-\mathrm{DET}$

$83 \% \quad t-\mathrm{BuOOH}, 4 \AA \mathrm{MS}$ $\mathrm{CH}_{2} \mathrm{Cl}_{2},-20^{\circ} \mathrm{C}$

Products and

Potential Drugs

\section{Key words}

sp-sp ${ }^{2}$ coupling

ruthenium

macrolactonization

Significance: Amphidinolide $\mathrm{P}$ is a cytotoxin isolated from the symbiotic dinoflagellates of the genus Amphidinium sp. found in the Okinawan flatworm Amphiscolops sp. Trost and co-workers use a highly chemo- and regioselctive Ru-catalyzed alkene-alkyne coupling reaction to construct the backbone of the natural product and disclose the first example of the use of a $\beta$-lactone as a 'thermodynamic spring' in macrolactonization.
Comment: The readily available fragments $\mathbf{C}$ and D undergo Ru-catalyzed alkene-alkyne coupling to give the 1,4-diene $\mathbf{E}$ comprising of the entire backbone of the natural product. A Sharpless asymmetric epoxidation of $\mathbf{E}$ gave the epoxide $\mathbf{F}$ that underwent macrolactonization upon treatment with Otera's catalyst $\mathbf{1}$ to give the adduct $\mathbf{G}$. Treating $\mathbf{H}$ with catalyst $\mathbf{1}$ effected a macrolactonization/hemiacetal forming reaction to give Amphidinolide $\mathrm{P}$ 